Gerontologia 1968;14:I-IV

\title{
Contents, Vol. 14, 1968
}

Gerontologia

Journal of Experimental Biological and Experimental Medical

Research on Ageing - Zeitschrift für experimentell-biologische und -medizinische Alternsforschung - Journal de Recherches expérimentales, biologiques et médicales, sur le vieillissement

Editor F. Verzár, Basel

Coeditores

F. Bourlière, Paris

D. A. Hall, Leeds

N. W. Shock, Baltimore, Md.

Collaboratores

A. v. Albertini, Zurich

W. Andrew, Indianapolis, Ind.

J. Baló, Budapest

J. Banga, Budapest

L. Binet, Paris

J. E. Birren, Bethesda, Md.

G. H. Bourne, Atlanta, Ga.

A. Comfort, London

J. Danielli, London

W. Doberauer, Wien

G. Di Macco, Roma

A. V. Everitt, Sydney

K. J. Franklin, London

S. M. Friedmann, Vancouver

T. Geill, København

T. Gillman, Cambridge

E. Greppi, Firenze

J. Groen, Jerusalem

H. Guth, Basel

H. P. von Hahn, Basel

L. Haranghy, Budapest

W. J. E. Jessop, Dublin

V. R. Khanolkar, Bombay

P. S. Krishnan, Lucknow

P. L. Krohn, Birmingham

P. J. Lindop, London

K. Miescher, Basel

H. Mislin, Mainz 
O. Mühlbock, Amsterdam

R. Nicolaysen, Oslo

F. Roulet, Basel

J. H. Sheldon, Wolverhampton

R. E. Tunbridge, Leeds

A. L. Vischer, Basel

R. Wagner, München

A. Welford, Cambridge

1968

Vol. 14

BASEL (Switzerland) S. KARGER NEW YORK

All rights, including that of translation into other languages, reserved.

Photomechanic reproduction (photocopy, microcopy) of this volume or parts thereof without special

permission of the publishers is prohibited.

(C)

Copyright 1968 by S. Karger AG, Basel

Printed in Switzerland by Buchdruckerei National-Zeitung AG, Basel

Cliches: Aberegg-Steiner \& Cie. AG, Bern

Index

Aksu, Y.: vide Kayahan, S.

Beregi, Edit and Perenyi, L.: Quantitative Studies on Immunofluorescence in

Allergic Changes of Old and Young Animals

80

Bourlière, F.: vide Henrotte, J. G.

Carlson, L. A.; Fröberg, S. O. and Nye, E. R.: Effect of Age on Blood and

Tissue Lipid Levels in the Male Rat 69

Comfort, A.: Physiology, Homoeostasis and Ageing 224

Fröberg, S. O.: vide Carlson, L. A. Gasperi, R. N. de : vide Lo, Chu-Shek Gordon, H. A.: vide Rovin, S.

Griew, S.: Age and Sex Differences in Probability Learning of Rats in a Swimm ing T-Maze 197

Hall, D. A.: Age Changes in the Levels of Elastase and its Inhibitor in Human

Plasma 97

Henrotte, J. G. et Bourlière, F.: Variability saisonnière du taux plasmatique

et urinaire des ions alcalins chez Thomme jeune et âgé $\quad 45$

Holmberg, P. C: vide Jalavisto, Eeva

Jalavisto, Eeva and Holmberg, P. C.: Day-to-Day Fluctuations in some

Physiological Variables of Elderly Women 180

Joseph, N. R.: Electrolyte Balance and Cellular Aging

Kayahan, S. and Aksu, Y.: The Effect of Penthobarbital on Stimulation Thre

shold in Young and Old Subjects 210

Kudejko, J.: Effect of Vitamin D3 and Induced Calciphylaxis on Atherosclerosis

of Rabbits Treated with Cholesterol and Calcium Gluconate 35

Lewi, S.: Observations sur les iso-anticorps du système ABO et sur les effets de la stimulation par les substances de groupe $\quad 160$ 
Little, K. and de Valderrama, J. A. Fernandez : Some Mechanisms Involved in the Osteoporotic Process 109

Lo, Chu-Shek; de Gasperi, R. N. and Ring, G. C: Aging and Whole Body Electrolytes in Inbred A $\times$ C Rats

Mainwaring, W. I. P.: The Effect of Testosterone on the Age-Associated Changes in the Ventral Prostate Gland of the Mouse; Testosterone and Ageing of the Prostate 133

Mitolo, M.: Electromyography on Aging 54

Nye, E. R.: vide Carlson, L. A.

Perényi, L.: vide Beregi, Edit

Ring, G. C.: vide Lo, Chu-Shek

Rovin, S. and Gordon, H. A.: The Influence of Aging on Wound Healing in

Germfree and Conventional Mice

87

Schlettwein-Gsell, Daniela : Veränderungen in der Ernährung alter alleinstehender Frauen nach dem 70. Lebensjahr 216

Sobel, H.: Aging of Connective Tissue and Molecular Transport 235

Takács, I. and Verzár, F.: Macromolecular Aging of Collagen. I. Experiments in vivo and in vitro with Different Animal Races

Takács, I. and Verzár, F.: Macromolecular Aging of Collagen. II. The Role Index

of Water Content, Solubility and Swelling Capacity of Tendon Fibers

During Aging and Storage 24

Takács, I. and Verzár, F.: Macromolecular Aging of Collagen. III. Stimula

tion of Collagen Production in the Skin and Uterus 126

Takács, I.: Collagen Content of Ovary and Testis of Rats During Ageing ... 174

Valderrama, J. A. Fernandez de : vide Little, K.

Verzár, F.: vide Takács, I.

Wetherick, N. E.: Age and Short-Term Memory Capacity for Familiar and

Unfamiliar Material 204

Book Review - Buchbesprechung - Livre nouveau

196

Varia

62

Obituary

195

Index rerum ad Vol. 14 